Document downloaded from:

http://hdl.handle.net/10251/83424

This paper must be cited as:

Andres-Colas, N.; Perea García, A.; Mayo, S.; Garcia-Molina, A.; Dorcey, E.; RodríguezNavarro, S.; Perez Amador, MA.... (2013). Comparison of global responses to mild deficiency and excess copper levels in Arabidopsis seedlings. Metallomics. 5(9):1234-1246. doi:10.1039/c3mt00025g.

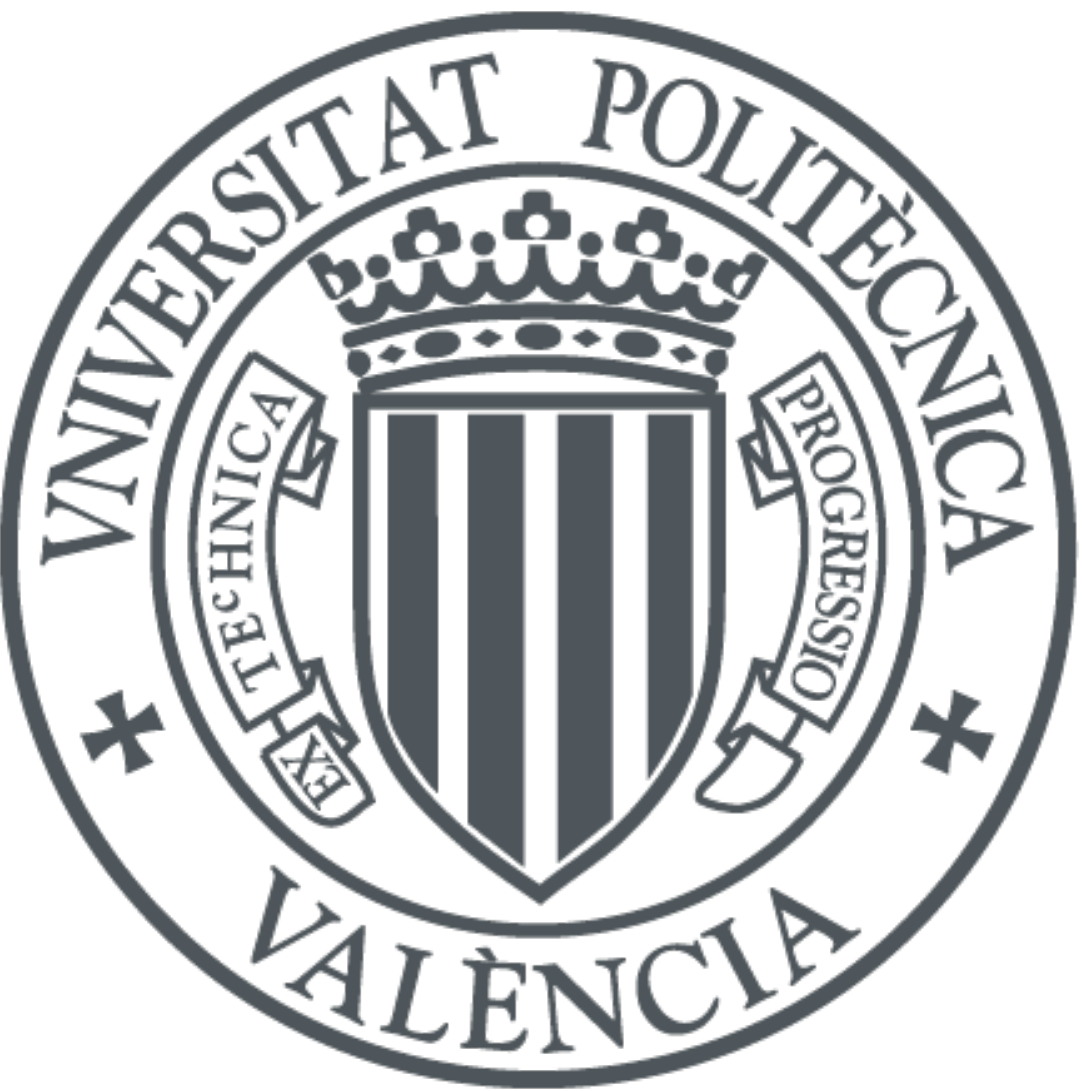

The final publication is available at

http://doi.org/10.1039/c3mt00025g

Copyright Royal Society of Chemistry

Additional Information 
Cite this: DOI: $10.1039 / \mathrm{c} 3 m+00025 \mathrm{~g}$

\section{Comparison of global responses to mild deficiency and excess copper levels in Arabidopsis seedlings $\dagger$}

\author{
Nuria Andrés-Colás, ${ }^{a}$ Ana Perea-García, ${ }^{a}$ Sonia Mayo de Andrés, $\ddagger^{a}$ Antoni \\ Garcia-Molina, $\S^{\mathrm{a}}$ Eavan Dorcey, ${ }^{\mathrm{b}}$ Susana Rodríguez-Navarro, $\boldsymbol{q}^{\mathrm{a}}$ \\ Miguel A. Pérez-Amador, ${ }^{b}$ Sergi Puig $\|^{a}$ and Lola Peñarrubia*a
}

Copper is an essential micronutrient in higher plants, but it is toxic in excess. The fine adjustments required to fit copper nutritional demands for optimal growth are illustrated by the diverse, severe symptoms resulting from copper deficiency and excess. Here, a differential transcriptomic analysis was done between Arabidopsis thaliana plants suffering from mild copper deficiency and those with a slight copper excess. The effects on the genes encoding cuproproteins or copper homeostasis factors were included in a CuAt database, which was organised to collect additional information and connections to other databases. The categories overrepresented under copper deficiency and copper excess conditions are discussed. Different members of the categories overrepresented under copper deficiency conditions were both dependent and independent of the general copper deficiency transcriptional regulator SPL7. The putative regulatory elements in the promoter of the copper deficiency overrepresented genes, particularly of the iron superoxide dismutase gene FSD1, were also analysed. A 65 base pair promoter fragment, with at least three GTAC sequences, was found to be not only characteristic of them all, but was responsible for most of the FSD1 copper-dependent regulations. Moreover, a new molecular marker for the slight excess copper nutritional status is proposed. Taken together, these data further contribute to characterise copper nutritional responses in higher plants.
Received 22nd January 2013, Accepted 13th February 2013

DOI: $10.1039 / \mathrm{c} 3 \mathrm{mt} 00025 \mathrm{~g}$

www.rsc.org/metallomics for cereal crops since the eighteenth century ${ }^{1}$ and, nowadays, it is one of the few anti-microbial treatments allowed in organic farming. ${ }^{2}$ However, given $\mathrm{Cu}$ phytotoxicity ${ }^{1,3,4}$ and the persistence of environmental $\mathrm{Cu},{ }^{5}$ the use of $\mathrm{Cu}$ in crops has to be optimised. ${ }^{6}$ In fact, the European Union has already voiced some concerns about the abuse of Cu-based crop treatments. ${ }^{7}$ Deficiency or low $\mathrm{Cu}$ bioavailability in soil also affects plant productivity, causes major economic losses and reduces the nutritional value of crops, thus affecting human food. $\mathrm{Cu}$ deficiency alters the functioning of electron transport chains in both mitochondria and chloroplasts through the malfunctioning of cuproproteins such as cytochrome $c$ oxidase and plastocyanin. Plants, as well as other eukaryotes, have developed sophisticated mechanisms to tightly control $\mathrm{Cu}$ homeostasis in response to changing environmental $\mathrm{Cu}$ bioavailability. Recent studies with Arabidopsis thaliana (A. thaliana) have allowed the characterisation of the diverse families and components involved in plant metal acquisition, distribution and tolerance. ${ }^{8,9}$ Furthermore, gene expression analyses now decipher coordinated mechanisms of regulation and response to $\mathrm{Cu}$ limitation. ${ }^{10,11}$ With the exception of transcriptional regulators, all the components of $\mathrm{Cu}$ homeostasis networks

\footnotetext{
T Present address: Centro de Investigación Príncipe Felipe. Autopista del Saler 16, E-46013, Valencia, Spain.

|| Present address: Departamento de Biotecnología, Instituto de Agroquímica y Tecnología de Alimentos (IATA), Agencia Estatal Consejo Superior de Investigaciones Científicas (CSIC), Ave. Agustín Escardino 7, E-46780, Paterna (Valencia), Spain. Dr Moliner 50,ES-46100 Burjassot,Valencia, Spain.E-mail: penarrub@uv.es, angarmo3@uv.es, srodriguez@ochoa.fib.es,spuig@iata.csic.es,penarrub@uv.es; Fax: +34-963544635; Tel: +34-963543013 Valencia, Spain.E-mail: eabhan@gmail.com, mpereza@ibmcp.upv.es c3mt00025g sitario y Politécnico La Fe. Avda. Campanar 21, E-46009, Valencia, Spain.
} 
1 seem to be conserved in eukaryotes. ${ }^{12}$ Briefly, $\mathrm{Cu}$ uptake into the cytosol in eukaryotes takes place through a family of cellsurface high affinity $\mathrm{Cu}$ transport proteins, denoted CTR and COPT, in yeast/animals and plants, respectively. In A. thaliana, different results suggest that COPT1 and COPT2 are plasma membrane proteins, whereas COPT3 and COPT5 proteins function in intracellular $\mathrm{Cu}$ distribution. ${ }^{13}$ Under conditions of low $\mathrm{Cu}$ availability, the expression of plasma membrane metal permeases COPT1 and COPT2, which mediate high 10 affinity $\mathrm{Cu}$ transport towards the cytosol, is activated. ${ }^{14}$ COPT1 participates in $\mathrm{Cu}$ uptake from soil through the root apex. ${ }^{15}$ Moreover, COPT5 is involved in the mobilisation of $\mathrm{Cu}$ from the lumen of the vacuole or prevacuolar compartments towards the cytosol in response to extreme $\mathrm{Cu}$-deficient conditions. ${ }^{16,17}$

15 Other components in the $\mathrm{Cu}$ homeostasis network are soluble cytosolic cuprochaperones, ${ }^{18}$ one of their tasks is to provide $\mathrm{Cu}$ to cytosolic targets, such as the CCS cuprochaperone, which delivers $\mathrm{Cu}$ to the $\mathrm{Cu}$ and zinc $(\mathrm{Zn})$ superoxide dismutase $(\mathrm{Cu}$ ) ZnSOD). ATX1 is another cuprochaperone that delivers $\mathrm{Cu}$ to

20 the P-type ATPases of $\mathrm{Cu}^{+}\left(\mathrm{Cu}^{+}\right.$-ATPases $)$at the endoplasmic reticulum to pump $\mathrm{Cu}$ into the lumen, where it is loaded into cuproproteins in the secretory pathway. Arabidopsis thaliana has two homologues of this cuprochaperone: ATX1 and $\mathrm{CCH}{ }^{8}$ Based on the presence of conserved Cu-binding motifs, ${ }^{19}$ it has been proposed that more than 200 proteins encoded by the $A$. thaliana genome bind $\mathrm{Cu}$. The function of only a small fraction of them is already known, including plastocyanin, cytochrome $c$ oxidase, ethylene receptors, multicopper oxidases (MCO), the laccases involved in the synthesis of extracellular matrix components, and MCO, LPR1 and LPR2 related to the perception of phosphate starvation responses. ${ }^{20}$

The transcriptional response to $\mathrm{Cu}$ deficiency in A. thaliana is mediated by one member of the $\mathrm{Zn}$ finger transcription factor family, namely SQUAMOSA-promoter binding-like protein (SPL). SPL7 is essential for responses to $\mathrm{Cu}$ deficiency in vivo through its binding to the GTAC motifs in the promoter of target genes. ${ }^{10,11}$ Although the mechanism remains currently unknown, the SPL7 repression in the presence of $\mathrm{Cu}$ can be mediated by the displacement of $\mathrm{Zn}$ by $\mathrm{Cu}$ from the $\mathrm{Zn}$ fingers of the transcription 0 factor, as recently described in vitro for the Chlamydomonas reinhardtii orthologue. ${ }^{21}$ One of the several SPL7-mediated strategies used by $A$. thaliana when $\mathrm{Cu}$ is limited is to replace nonessential cuproproteins with other metalloproteins, usually iron (Fe) proteins, that carry out a similar role, probably to save $\mathrm{Cu}$ for 45 essential cuproproteins such as plastocyanin. ${ }^{22}$ Substitution of $\mathrm{Cu} / \mathrm{ZnSOD}$ for FeSOD under Cu-limited conditions is carried out by the SPL7 transcription factor, which activates the expression of FSD1 (encoding chloroplastic FeSOD) and promotes the degradation of $\mathrm{Cu} / \mathrm{ZnSOD}$ mRNAs through the induction of microRNA miR398. ${ }^{23}$ Other Cu-regulated miRNAs include miR397, miR408 and miR857, which are involved in the degradation of the mRNAs encoding cuproproteins such as plantacyanins and laccases. ${ }^{23,24}$ Therefore, regulation by miRNAs is a widespread response to $\mathrm{Cu}$ deficiency, as is the case for other nutrients. ${ }^{20}$

Although large-scale gene expression analyses under $\mathrm{Cu}$ deficiency conditions have been recently reported, ${ }^{10,11}$ genome-wide changes affecting plants under mild $\mathrm{Cu}$ excess conditions have not yet been characterised. Furthermore, the use of molecular markers for the $\mathrm{Cu}$ nutritional status is important in crops in order to establish the endogenous metal content perceived by plants and to prevent the deleterious toxicological effects deriving from excess $\mathrm{Cu}$ supply. A marker for mild $\mathrm{Cu}$ stress would be of interest to adjust the appropriate $\mathrm{Cu}$ dose in crop treatments and to anticipate any reduction in the physiological parameters leading to diminished plant production if excess $\mathrm{Cu}$ supply continues. However, most gene expression analyses under $\mathrm{Cu}$ excess conditions have been carried out at high $\mathrm{Cu}$ concentrations $(25-50 \mu \mathrm{M})$, where reduced growth and other physiological symptoms are already evident. ${ }^{25-29}$ The main objectives of the current work are to define $\mathrm{Cu}$ sufficiency limits at the molecular level and to provide new molecular markers for mild $\mathrm{Cu}$ deficiency and excess conditions. For these purposes, global changes in the gene expression under mild $\mathrm{Cu}$ deficiency and $\mathrm{Cu}$ excess conditions were compared. Information on $\mathrm{Cu}$ homeostasis factors was compiled in a CuAt database (www.uv.es/cuatlab/cuatdb). Moreover, the analysis of a cis regulatory element in FSD1, one of the best overrepresented genes under conditions of $\mathrm{Cu}$ deficiency $v s$. excess, is presented. The results shown herein underscore the differential regulation of the $\mathrm{Cu}$ homeostasis network and several general cellular processes, further contributing to understand plant responses to a mild Cu-unbalanced supply.

\section{Results and discussion}

\section{Metal content under conditions of different $\mathrm{Cu}$ availabilities}

In order to evaluate endogenous metal content in accordance with the $\mathrm{Cu}$ present in the medium, we grew A. thaliana seedlings for 6 days on homemade $\mathrm{MS}$ plates ${ }^{30}$ with $\mathrm{Cu}$ concentrations ranging from 0 to $50 \mu \mathrm{M}$. In addition, commercial MS (Sigma) plates with and without the $\mathrm{Cu}$ chelator bathocuproinedisulphonic acid (BCS) at $100 \mu \mathrm{M}$ were also included (Fig. 1). As expected, endogenous $\mathrm{Cu}$ concentrations increased as $\mathrm{Cu}$ was added to the medium. According to the sufficiency range (5-20 $\mu$ g per gram of dry weight), ${ }^{31}$ the $\mathrm{Cu}$ concentrations in the medium below $0.5 \mu \mathrm{M}$ represented suboptimal $\mathrm{Cu}$ availability for plants, whereas those in the medium above $5 \mu \mathrm{M} \mathrm{Cu}$ constituted excess for the seedlings grown on plates (Fig. 1). We should note that standard commercial MS medium, widely utilised by the $A$. thaliana community often as the control condition, is included within the mild $\mathrm{Cu}$ deficiency range $(2.13 \pm$ $1.07 \mu \mathrm{g} \mathrm{Cu}$ per gram of dry weight), a fact also indicated by other laboratories. ${ }^{10,22}$ The levels of the two other metals participating in the SOD substitution process in plants, $\mathrm{Zn}$ and $\mathrm{Fe}$, were also measured (Fig. 1). Both metals remained at the sufficiency levels within the whole $\mathrm{Cu}$ concentration range used in the experiment. Zn concentration slightly, but significantly, increased within the $\mathrm{Cu}$ excess range, whereas Fe content slightly increased as $\mathrm{Cu}$ increased within the $\mathrm{Cu}$ deficiency and sufficiency range, but decreased under $\mathrm{Cu}$ excess conditions (Fig. 1).

No differences in symptoms were observed in the wild-type (WT) plants grown within the $\mathrm{Cu} 0$ to $10 \mu \mathrm{M}$ range. Thus, root growth, a sensitive parameter to $\mathrm{Cu}$ levels, remained unaltered 


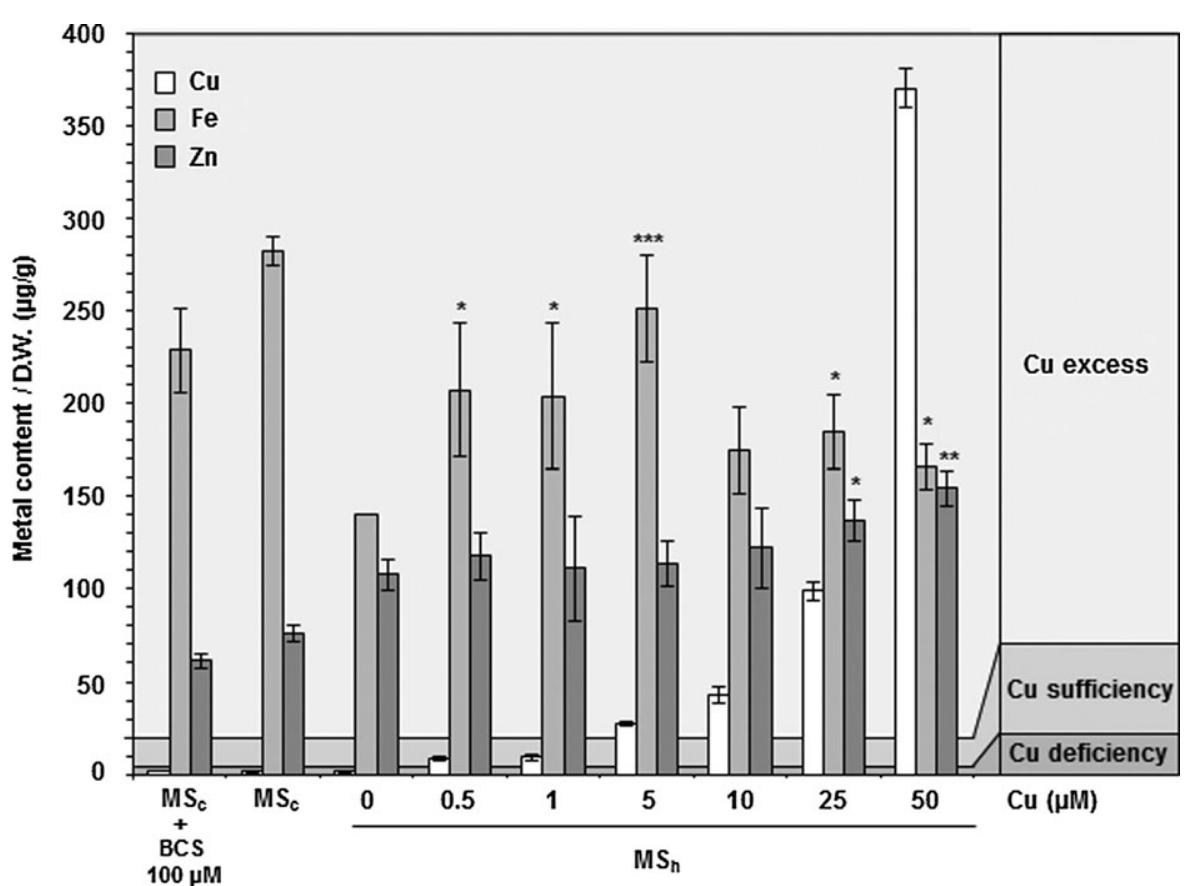

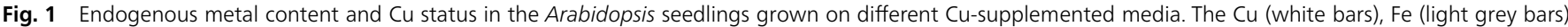

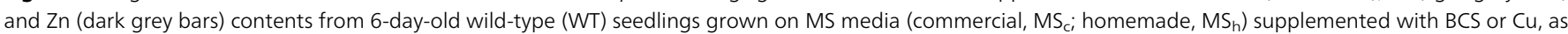

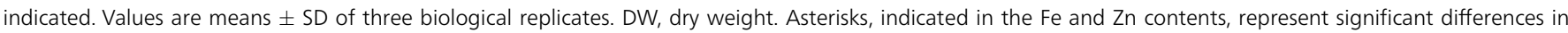
relation to the Cu $0 \mu \mathrm{M}$ medium $\left({ }^{*} P<0.05 ;{ }^{* *} P<0.01 ;{ }^{* *} P<0.005\right)$. The deficiency, sufficiency and excess ranges are indicated. ${ }^{31}$

within this $\mathrm{Cu}$ concentration range, and up to at least $20 \mu \mathrm{M} \mathrm{Cu}$ (Fig. S1a, ESI $\dagger$ ). Other parameters, such as lipid peroxidation (measured as malondialdehyde, MDA, content) and chlorophyll content, showed no significant changes at $\mathrm{Cu}$ concentrations below $25 \mu \mathrm{M}$ (Fig. S1b and c, ESI $\dagger$ ). Moreover, the A. thaliana plants grown on soil under either $\mathrm{Cu}$ deficiency (no added $\mathrm{Cu}$ ) or $\mathrm{Cu}$ excess $(100 \mu \mathrm{M} \mathrm{Cu})$ conditions showed apparently similar visual symptoms when compared to sufficiency $(2.5 \mu \mathrm{M} \mathrm{Cu})$, such as leaf chlorosis, reduced size and fertility (Fig. S2, ESI + ), hindering the $\mathrm{Cu}$ nutritional status diagnosis.

\section{Gene expression changes under conditions of different $\mathrm{Cu}$ availabilities}

40 In order to better characterise the higher plant responses at the molecular level to the sub- and supra-optimal Cu levels in the growth medium, a global profiling analysis of gene expression under limiting or exceeding $\mathrm{Cu}$ conditions was performed. We chose pre-symptomatic $\mathrm{Cu}$ concentrations. Hence changes in gene expression represent adaptive responses rather than secondary growth or toxicity effects. In addition, our analyses present other novelties and advantages, such as the minimised contribution of general stress responses since both conditions represent mild stress, thus highlighting specific mild $\mathrm{Cu}$ deficiency or excess responses. To this end, A. thaliana seedlings were grown under a long day photoperiod for 6 days on commercial MS plates to be compared with the seedlings grown in the same medium supplemented with $10 \mu \mathrm{M} \mathrm{Cu}$. Hereafter, these two $\mathrm{Cu}$ status conditions are, respectively, denoted low $\mathrm{Cu}$ and high $\mathrm{Cu}$ since the endogenous $\mathrm{Cu}$ levels in MS were below the optimal supply, but were above the excess threshold at $10 \mu \mathrm{M} \mathrm{Cu}$ (Fig. 1). ${ }^{31}$ In order to validate the microarray conditions for low and high $\mathrm{Cu}$, we determined the expression pattern of the genes previously described to be Cu-responsive by semi-quantitative PCR (sqPCR) (Fig. S3, ESI $\dagger$ ). The gene expression changes expected in the $\mathrm{Cu}$ homeostasis factors in response to low $\mathrm{Cu}$ include the aforementioned SOD substitution. While FSD1 had a lower expression under high $\mathrm{Cu}$ conditions as compared to low $\mathrm{Cu}$ conditions, the expression of the genes encoding both cytosolic and chloroplastic $\mathrm{Cu} /$ ZnSODs (CSD1 and CSD2, respectively) was higher (Fig. S3, ESI + ), as previously reported. ${ }^{22}$ Furthermore, the expression of transporters such as ZIP2 (ZRT, IRT-like protein 2) ${ }^{32}$ and COPT2 (ref. 13) was lower under high $\mathrm{Cu}$ conditions as compared to low $\mathrm{Cu}$ conditions, while that of HMA5, a P-type ATPase that plays a role in $\mathrm{Cu}$ efflux, ${ }^{33}$ was higher. Metallochaperones responded differentially to low $\mathrm{Cu}$ levels in accordance to their function. For example, $\mathrm{CCH}$ (copper chaperone), a plantspecific chaperone, ${ }^{34}$ was overrepresented under low vs. high $\mathrm{Cu}$ conditions, whereas under our experimental conditions, $C C S(\mathrm{Cu}$ chaperone for $\mathrm{Cu} / \mathrm{ZnSOD}$ and the only chaperone for both cytosolic and chloroplastic $\mathrm{Cu} / \mathrm{ZnSODs})^{35,36}$ was overrepresented under high $v s$. low $\mathrm{Cu}$ conditions (Fig. S3, ESI $)^{\text {). }}$

For the microarray expression analysis, samples were compared as high vs. low $\mathrm{Cu}$. A median $\log _{2}$ ratio of 1 (2-fold difference in expression) was used as a cut-off criterion. Of the 232 differentially expressed genes identified, 125 were overrepresented under high $\mathrm{Cu}$ conditions (ratio $>1$ ) and 107 were overrepresented under low $\mathrm{Cu}$ conditions (ratio $<-1$ ). The biological processes affected by $\mathrm{Cu}$ status were identified with the Gene Ontology (GO) annotation, ${ }^{37}$ performed with the 
1 Table 1 Functional categories overrepresented under low and high Cu conditions in Arabidopsis seedlings. Summary of the microarray analysis results from the 6-day-old wild-type (WT) seedlings grown on commercial MS media without (Low Cu) and with Cu $10 \mu \mathrm{M}$ (High Cu)

5 Low $\mathrm{Cu}$

\begin{tabular}{lllllll}
\hline $\begin{array}{l}\text { Functional } \\
\text { category }\end{array}$ & $\begin{array}{l}\text { No. of } \\
\text { genes }\end{array}$ & $\begin{array}{l}\text { Marker } \\
\text { gene }\end{array}$ & & $\begin{array}{l}\text { Functional } \\
\text { category }\end{array}$ & $\begin{array}{l}\text { No. of } \\
\text { genes }\end{array}$ & $\begin{array}{l}\text { Marker } \\
\text { gene }\end{array}$ \\
\hline $\begin{array}{l}\text { Ion } \\
\text { homeostasis }\end{array}$ & 10 & COPT2 & $\begin{array}{l}\text { Ion } \\
\text { homeostasis }\end{array}$ & 2 & CCS
\end{tabular}

10

Responses

to stress

17

$17 \quad$ FSD1

CYP706A

Responses

19

to stress

Sulphur

$13 \quad B U S 1$

metabolism

15

$\begin{array}{lll}\text { Cell growth } & 18 & \text { GDPD6 } \\ & & \text { EXPB3 }\end{array}$

DNA

modification

Cell division 18

EXPB3

Signal

transduction

22

$\operatorname{miR} 398 b$

$C A S$

ACA1
20

FatiScan (http://fatiscan.bioinfo.cipf.es/) and GeneCodis2.0 (http://genecodis.dacya.ucm.es/) programmes (Table 1). All the differentially expressed genes in the microarray are shown

in Tables S1 and S2 (ESI $\dagger$ ). The different genes involved in ion homeostasis, responses to stress, and signalling processes were overrepresented under each $\mathrm{Cu}$ condition. Yet DNA modification and cell division genes were overrepresented under high vs. low $\mathrm{Cu}$ conditions (Table S1, ESI $\dagger$ ), and sulphur metabolism and cell growth genes were overrepresented under low vs. high $\mathrm{Cu}$ conditions (Table S2, ESI $\dagger$ ).

\section{Establishment of a CuAt database}

35 The first category selected to be analysed in this work was ion homeostasis as it has been a main focal point in our laboratory in recent years. Certain genes participating in $\mathrm{Cu}$ homeostasis were overrepresented in this group (Table 1; Tables S1 and S2, ESI $\dagger$ ). In order to classify the $\mathrm{Cu}$ homeostasis-related factors

40 and to facilitate the search for information about $A$. thaliana $\mathrm{Cu}$ homeostasis components, we created a database which we called the CuAt database (Table S3, ESI $\dagger$ ). This compilation includes the proteins that bind $\mathrm{Cu},{ }^{19,38}$ and it is connected to other databases and websites (TAIR; Arabidopsis eFP Browser; the microarray value under the different $\mathrm{Cu}$ status analysed in this work and the number of putative regulatory GTAC motifs in the 500 base pair (bp) promoters of the genes encoding $\mathrm{Cu}^{-}$ related proteins, are also included. The CuAt database is es/cuatlab) and it is modified as new relevant information on $\mathrm{Cu}$ homeostasis emerges. Table 2 summarises the seven families into which the CuAt database has been organised, along with the corresponding subgroups. The main families included in the CuAt database are transporters, chaperones, chelators, target cuproproteins and regulatory factors. We also
Table 2 CuAt database families. Summary of the number of $\mathrm{Cu}$ homeostasisrelated genes arranged into families. The number of overrepresented members at either low or high Cu levels in the microarray analysis is also indicated for each subgroup. The total number of members for each subgroup is given in parentheses. The complete dataset is shown in Table S3, ESI

\begin{tabular}{|c|c|c|c|}
\hline \multirow[b]{2}{*}{ Family } & \multirow[b]{2}{*}{ Genome } & \multicolumn{2}{|c|}{ Microarray } \\
\hline & & $\begin{array}{l}\text { Low } \\
\mathrm{Cu}\end{array}$ & $\begin{array}{l}\text { High } \\
\mathrm{Cu}\end{array}$ \\
\hline \multicolumn{4}{|l|}{ 1. Cu Transporters } \\
\hline 1.1. COPT-type transporters & 6 & 1 & \\
\hline 1.2. Cu ATPases & $4(8)$ & & \\
\hline \multicolumn{4}{|l|}{ 1.3. Others } \\
\hline 1.3.1. ZIPs & $2(12)$ & 1 & \\
\hline 1.3.2. $\mathrm{Cu}$ chelators transporters & $2(9)$ & $1(1)$ & \\
\hline 1.3.3. Others & 1 & & \\
\hline 2. Cuprochaperones & 45 & 1 & 1 \\
\hline \multicolumn{4}{|l|}{ 3. $\mathrm{Cu}$ chelators } \\
\hline 3.1. Metallothioneins & $8(9)$ & 1 & (1) \\
\hline 3.2. Others & 5 & 2 & \\
\hline \multicolumn{4}{|l|}{ 4. Targets } \\
\hline 4.1. Ethylene receptor & 1 & & \\
\hline 4.2. $\mathrm{Cu} / \mathrm{Zn}$ superoxide dismutases & 3 & & 2 \\
\hline \multicolumn{4}{|l|}{ 4.3. Blue copper proteins or cuprodoxins } \\
\hline 4.3.1. Plastocyanin & 2 & & \\
\hline 4.3.2. Plantacyanin & 1 & & 1 \\
\hline 4.3.3. Others & $44(45)$ & & \\
\hline 4.4. Cytochrome $c$ oxidase & $31(85)$ & 1 & \\
\hline 4.5. Diamine oxidase & $17(26)$ & & \\
\hline \multicolumn{4}{|l|}{$\begin{array}{l}\text { 4.7. Blue oxidases or multicopper } \\
\text { oxidases (MCOS) }\end{array}$} \\
\hline 4.7.1. Ascorbate oxidases & $11(14)$ & & \\
\hline 4.7.2. Laccases & 17 & & \\
\hline 4.7.3. Others & $22(25)$ & & \\
\hline \multicolumn{4}{|l|}{ 5. Regulators } \\
\hline 5.1. SPLs & $3(17)$ & & \\
\hline 5.2. miRNAs & 7 & & \\
\hline \multicolumn{4}{|l|}{ 6. Others } \\
\hline 6.1. Reductases & $(8)$ & & \\
\hline 6.2. Mutants & 2 & & \\
\hline 7. Unclassified & 284 & 5 & 4 \\
\hline
\end{tabular}

included two other categories, these being miscellaneous components (others) and other Cu-related proteins, which remain unclassified to date (Table 2 and Table S3, ESI $\dagger$ ). The number of members already related to $\mathrm{Cu}$ homeostasis in a subgroup in terms of total number of members (shown in brackets) is also indicated, along with the number of genes overrepresented at low or high $\mathrm{Cu}$ levels in our microarray analysis (Table 2).

\section{Analysis by real-time quantitative PCR of the representative members of the Cu-regulated categories}

Representative members of each category that were overrepresented under low and high $\mathrm{Cu}$ conditions in our microarray analysis were selected from among the higher microarray values (Table 1) to determine their expression levels by real-time quantitative PCR (qPCR).

Global expression changes under high vs. low $\mathrm{Cu}$ (Table S1, ESI $\dagger$ ) conditions included the $\mathrm{Cu}$ homeostasis factors that had 
Fig. 2 Expression of the high Cu-representative genes in the Arabidopsis seedlings grown on different Cu-supplemented media. Relative expressions of the CCS, CSD1, SDH1-2, Rbohl, HDA18, BUB3.2, PRR5 and GRP7 genes. The total RNA from the 6-day-old WT seedlings grown on commercial MS medium without (MS; white bars) and with Cu $10 \mu \mathrm{M}$ (Cu; grey bars) was isolated and retrotranscribed to CDNA. The mRNA amounts of each gene were measured by qPCR with specific primers and were normalised to the UBQ 10 expression. mRNA levels are expressed in relative units to the high $\mathrm{Cu}$ conditions. Values are the means $\pm S D$ of four biological replicates. Asterisks represent significant differences $(P<0.05)$.

already been reported to respond to $\mathrm{Cu}$ status. In this sense, the $C C S$ expression was used as a control in qPCR for high $\mathrm{Cu}$ overrepresented genes (Fig. 2). According to the oxidative stress sentatives in this category was CSD1, which was already reported to respond to $\mathrm{Cu}$ status, and was confirmed by qPCR under our conditions. Moreover, the expression of a nuclear gene encoding the flavoprotein subunit of succinate dehydrogenase, $S D H 1-2,{ }^{39}$ was also checked and confirmed (Fig. 2), indicating the mitochondrial involvement in the perception/ signalling of these oxidative stress conditions. Furthermore, the expression of the guard cells and root xylem NADPH respiratory burst oxidase $R b o h I^{40}$ also increased under high vs. low $\mathrm{Cu}$ conditions (Fig. 2), suggesting a deliberate generation of reactive oxygen species (ROS) as part of the $\mathrm{Cu}$ signalling process. In the DNA modification and cell division categories, the genes encoding histone deacetylase 18 (HDA18) and BUB3.2 were the candidates chosen to check their expressions by qPCR (Fig. 2). BUB3.2 encodes a homologue of the yeast and human BUB3 (BUDDING UNINHIBITED BY BENZYMIDAZOL 3) protein, which functions in the spindle assembly checkpoint control. $^{41}$

It is noteworthy that while morning members of the circadian clock, e.g., $L H Y$ and CCA1, are overrepresented under $\mathrm{Cu}$ deficiency (Table S2, ESI $\dagger$ ) conditions, as previously reported, ${ }^{42}$ evening circadian clock components pseudoresponse regulator $P R R 5$ and glycine-rich RNA-binding protein GRP7 (ref. 43 and 44) are among the best representatives in the signalling category under high $\mathrm{Cu}$ (Table S1, ESI $\dagger$ ) conditions, whose expression was also corroborated by qPCR (Fig. 2). These results further reinforce the proposed interaction between $\mathrm{Cu}$ homeostasis and the circadian clock. ${ }^{42}$

Of the genes overrepresented under low $\mathrm{Cu}$ conditions (Table $\mathrm{S} 2, \mathrm{ESI} \dagger$ ), SPL7 is the master transcriptional activator under $\mathrm{Cu}$ deficiency conditions. ${ }^{10}$ COPT2 and FSD1 are among the best representative genes under low $\mathrm{Cu}$ conditions and their expression patterns are mostly dependent on SPL7. ${ }^{10} \mathrm{We}$ used the FSD1 expression as a control of SPL7-dependent regulation by checking its expression in the $\operatorname{spl} 7$ mutant at the different $\mathrm{Cu}$ levels (Fig. 3). The substitution of Fe SOD for the $\mathrm{Cu}-\mathrm{Zn}$ SOD counterpart is a well-documented process which occurs under Cu-deficiency conditions and is mediated by the miR398 expression targeting $C S D 1$ and $C S D 2 .{ }^{23}$ It is worth mentioning that in addition to miR398, our data show other miRNAs (miR165, miR169, miR319 and miR395) that target drought resistance, sulfate transport and circadian-related transcription factors, ${ }^{45}$ which are overrepresented under $\mathrm{Cu}$ deficiency conditions (Table S2, ESI $\dagger$ ).

COPT2 has been shown to be partially dependent on SPL7, as published elsewhere. ${ }^{10}$ Among the most highly expressed genes in the stress category we find CYP706A1, which encodes a cytochrome $\mathrm{P} 450$ family member. In addition to the expression obtained in the microarray (Table S2, ESI $\dagger$ ), this gene's $\mathrm{Cu}$-regulated expression was corroborated by qPCR and was shown to be partially dependent on SPL7 (Fig. 3). Another member of the cytochrome P450 family, CYP79F1, also known as BUS1 and related to the aliphatic glucosinolate biosynthetic pathway from methionine, ${ }^{46}$ was selected in the sulphur biosynthesis category. BUS1 was also partially SPL7-dependent (Fig. 3). In addition to BUS1, other genes specifically involved in this pathway (e.g., CYP83A1, MAM1, GSTF11 and UGT74C1) were overrepresented under $\mathrm{Cu}$ deficiency conditions (Table S2, ESI $\dagger$ ). In the cell expansion category, glycerophosphodiester phosphodiesterase GDPD6 and expansin EXPB3 were seen to be among the most differentially expressed genes, and their expressions were confirmed by qPCR. Whereas the GDPD6 expression was mostly independent of SPL7, the EXPB3 expression was partially SPL7-dependent (Fig. 3). The expansin EXPB3 expression was demonstrated to be repressed by the E2Ff transcription factor ${ }^{47}$ which, accordingly, had a $\log _{2}$ ratio of +1.459 under our experimental conditions (Table S1, ESI $\dagger$ ). Moreover, the other genes regulated by E2Ff, such as EXPA8, $U G T 74 C 1$ and $U G T 78 D 2$, also obtained high values in our microarrays (Table S2, ESI $\dagger$ ). Finally in the signalling category, $C A S$ was one of the best representative genes, which encoded a chloroplast-localised protein, and is considered a primary 

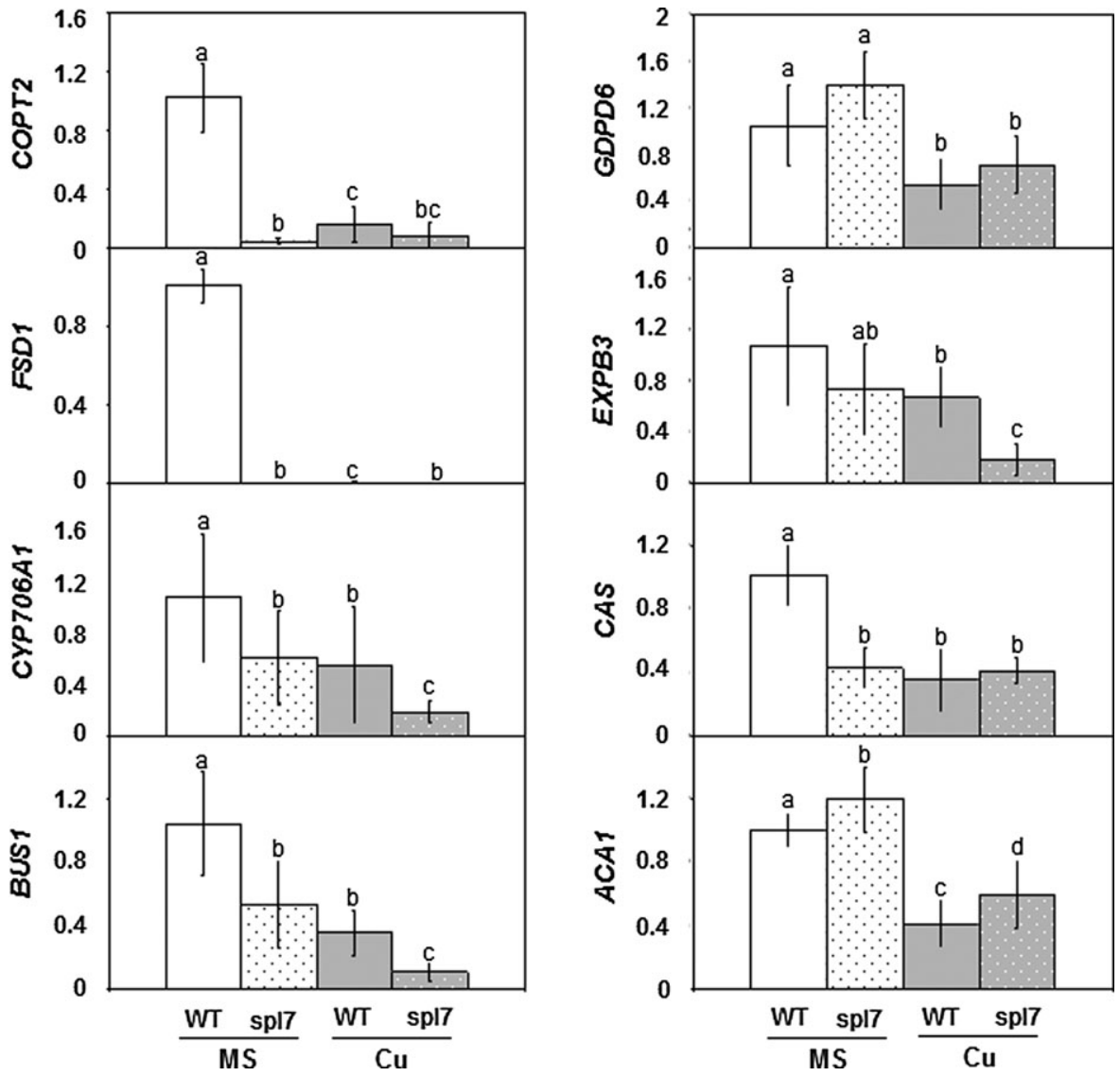

Fig. 3 Expression of the low Cu-representative genes in the Arabidopsis seedlings grown on different CU-supplemented media. Relative expressions of the COPT2, FSD1, CYP706A1, BUS1, GDPD6, EXPB3, CAS and ACA1 genes. The total RNA from the 6-day-old WT (plain bars) and the SPL7 knockout (spl7; dotted bars) seedlings grown on commercial MS medium without (Low Cu; white bars) and with $\mathrm{Cu} 10 \mu \mathrm{M}$ (High Cu; grey bars) was isolated and retrotranscribed to CDNA. The mRNA amounts of each gene were measured by qPCR with specific primers and were normalised to the UBQ10 expression. mRNA levels are expressed in relative units to WT seedlings under low $\mathrm{Cu}$ conditions. Values are the means \pm SD of at least five biological replicates. The different letters above the bars represent significant differences $(P<0.05)$. expression under low $v s$. high Cu conditions was SPL7-dependent (Fig. 3). Moreover, carbonic anhydrase ACA1 was another calcium-related representative gene in this category, whose expression was SPL7-independent (Fig. 3).

Despite the differences with other global analysis studies, the COPT2, FSD1, CYP706A1, CAS and ACA1 expressions in seedlings (Fig. 3) reproduce the pattern previously described when comparing adult (6-week-old) Columbia (Col 0) and spl7-2 mutant plants in a recent whole transcriptome RNA-Seq analysis. ${ }^{11}$

The promoters of some of the most overrepresented genes under low $\mathrm{Cu}$ conditions exhibit three or more GTAC boxes in a promoter region shorter than $65 \mathrm{bp}$ included in the $500 \mathrm{bp}$ upstream of the gene transcriptional start (Table 3). Despite a single GTAC box being described as responsive to $\mathrm{Cu}$ deficiency SPL7-mediated transcriptional regulation, ${ }^{10}$ a theoretical global study conducted on the $500 \mathrm{bp}$ proximal promoters of our microarray genes indicated no correlation between the presence of a putative GTAC box and their $\mathrm{Cu}$ regulation (Table 3). Accordingly, the average number of expected GTAC boxes in $500 \mathrm{bp}$ is 1.941 , accounting for there being every likelihood of finding this short motif in relatively long
Table 3 Cu regulation and GTAC boxes in gene promoters. Summary of the number of genes with the indicated characteristics. The number of genes overrepresented at either low or high $\mathrm{Cu}$ levels in the microarray analysis is also indicated for each characteristic. The promoter regions of $500 \mathrm{bp}$ upstream of the transcriptional start were used in this analysis. The $\leq 65$ bp region is included in the $500 \mathrm{bp}$ upstream of the gene transcriptional start

\begin{tabular}{lrrrr}
\hline & & \multicolumn{3}{l}{ Microarray } \\
\cline { 3 - 5 } & Genome & Total & Low Cu & High Cu \\
\hline Total genes & 33602 & 487 & 107 & 125 \\
Genes with GTACs & 18802 & 273 & 62 & 62 \\
Genes with $\geq 3$ GTACs in $\leq 65 \mathrm{pb}$ & 293 & 13 & 9 & 0 \\
\hline
\end{tabular}

sequences. However, recurrence of these boxes $(\geq 3$ GTAC boxes) in short regions ( $\leq 65 \mathrm{bp}$ in the 500 bp upstream) is quite unlikely $\left(1.977 \times 10^{-3}\right)$. The genes with these characteristic promoter elements found in the current study were FSD1, miR398b, ZIP2, COPT2, YSL2, CCH, LHY, CAS and SMC6B (Table 4 and Fig. S4, ESI $\dagger$ ), all of which were clearly overrepresented under $\mathrm{Cu}$ deficiency conditions (Table S2, ESI†). These findings enabled us to consider these GTAC repetitions as candidate cis elements, which are probably involved in transcriptional regulation under $\mathrm{Cu}$ deficiency conditions. 


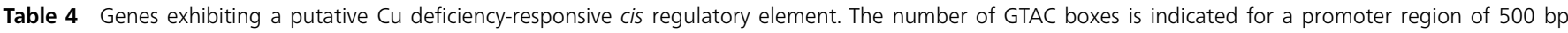

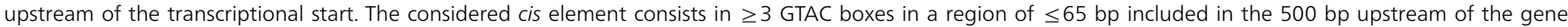
transcriptional start. The ratio value is the median $\log _{2}$ ratio at the high $v$ s. the low $C u$ levels in the microarray analysis

\begin{tabular}{|c|c|c|c|c|c|}
\hline Gene annotation & Gene name & MIPS code & No GTACs & No GTACs in $\leq 65$ bp & Ratio \\
\hline Fe superoxide dismutase & FSD1 & At4g25100 & 6 & 4 & -3.834 \\
\hline Target CSD1, CSD2 and Cyt $c$ oxidase members & $\operatorname{miR} 398 b$ & At5g14545 & 7 & 3 & -3.516 \\
\hline Zn transporter & ZIP2 & At5g59520 & 5 & 3 & -3.243 \\
\hline High-affinity $\mathrm{Cu}$ transporter & COPT2 & At3g46900 & 4 & 4 & -2.860 \\
\hline Oligopeptide transporter (yellow stripe-like) & YSL2 & At5g24380 & 4 & 3 & -2.593 \\
\hline $\mathrm{Cu}$ chaperone & $\mathrm{CCH}$ & At3g56240 & 4 & 4 & -1.819 \\
\hline Myb-related transcription factor & $L H Y$ & At1g01060 & 3 & 3 & -1.594 \\
\hline Chloroplast-localised calcium sensor & $C A S$ & At5g23060 & 5 & 3 & -1.497 \\
\hline Component of the SMC5/6 complex & $S M C 6 B$ & At5g61460 & 3 & 3 & -1.183 \\
\hline
\end{tabular}

In line with this, the FSD1 gene, based on both its response

15 to $\mathrm{Cu}$ deprivation and the presence of potential cis regulatory elements (its promoter has six GTAC boxes, four of which are included in $\leq 65 \mathrm{bp}$ ), is one of the best candidates as a marker gene of $\mathrm{Cu}$ deficiency (Fig. 3 and 4). In order to explore the regulation of the FSD1 gene expression in $\mathrm{Cu}$ deficiency in

20 greater detail, a chimeric construct was cloned, which included a fragment of 1193 nucleotides (nt) of its promoter containing the six GTAC boxes ( $p F S D 1$ ) fused with the uidA coding region for $\beta$-glucuronidase (GUS) from Escherichia coli ( $p F S D 1:: G U S$ ) (Fig. S5, ESI $\dagger$ ). To study the effect of its GTAC boxes on $1128 \mathrm{nt}$, where the $65 \mathrm{nt}$ region comprising the four GTAC boxes candidates to be involved in the $\mathrm{Cu}$ response was eliminated (pFSD1*), was fused with uidA ( $\left.p F S D 1^{*}:: G U S\right)$ (Fig. S5, ESI $\left.\dagger\right)$. Both constructs were sequenced to ensure integrity, cloned in the

30 binary pFP101 vector and used for Agrobacterium-mediated transformation by floral dipping. ${ }^{49}$ A sqPCR analysis of the $G U S$ and FSD1 expressions in both transgenic seedling types grown on the described low and high $\mathrm{Cu}$ media was done (Fig. 4a). Whereas GUS behaved similarly to the endogenous FSD1 gene in terms of

$35 \mathrm{Cu}$ deficiency responsiveness in the pFSD1::GUS plants, GUS induction was lost mostly in the plants from which the four GTAC boxes were eliminated $\left(p F S D 1^{*}:: G U S\right)$. In order to quantify this effect, qPCR was performed for the GUS transcript. As shown in Fig. 4b, most of the induction (above 99.9\%) was lost when

40 the four GTAC boxes were eliminated from two independent transgenic lines, indicating the importance of this element ( $\geq 3$ GTAC boxes in $\leq 65 \mathrm{bp}$ in the 500 bp upstream of the ATG) for Cu-responsive genes. This result suggests the possibility of designing strategies to test Cu-deficiency by fusing $p F S D 1$ to amenable reporters in agricultural practices.

\section{Defining nutritional $\mathrm{Cu}$ ranges at the molecular level}

In order to further characterise the concentration range within which the transcriptional regulation of some of these genes takes place, seedlings were grown in different media with $\mathrm{Cu}$ concentrations ranging from 0 to $0.7 \mu \mathrm{M}$. The expression of two well-known $\mathrm{Cu}$ deficiency-responsive genes, FSD1 and $\mathrm{CCH}$, was checked by qPCR (Fig. 5a). Moreover, two genes whose expression is already known to be induced by high $\mathrm{Cu}$, CSD1 and $C C S$ were also analysed within the same concentration range (Fig. 5b). FSD1 exhibited 50\% of its maximum expression (a)

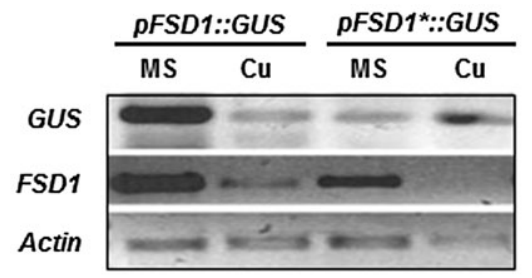

(b)

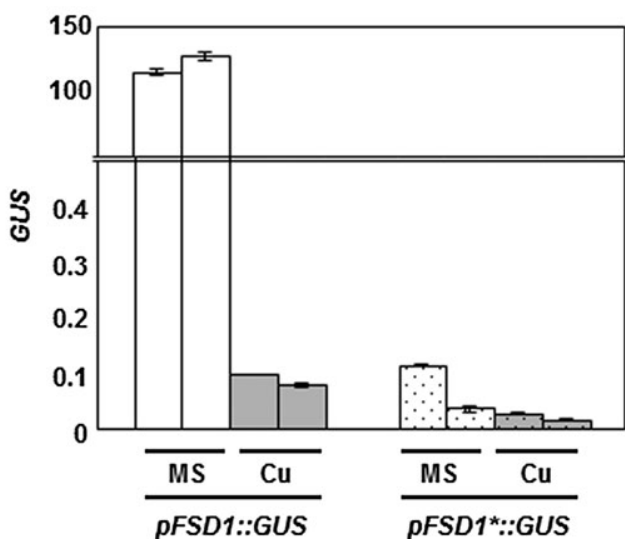

Fig. 4 Functionality of the FSD1 putative Cu deficiency-responsive cis regulatory element in Arabidopsis seedlings. Expressions of the GUS and FSD1 genes. The total RNA from the 6-day-old pFSD1::GUS (plain bars) and pFSD 1 *:::GUS (-4GTAC boxes in $\leq 65 \mathrm{bp}$ included in the $500 \mathrm{bp}$ upstream of the gene transcriptional start; dotted bars) transgenic seedlings grown on commercial MS medium without (MS; white bars) and with $\mathrm{Cu} 10 \mu \mathrm{M}$ (Cu; grey bars) was isolated and retrotranscribed to CDNA. The sqPCR products for GUS and FSD1 are shown in (a) with Actin mRNA as the loading control. In (b), the mRNA amounts of GUS were measured by $\mathrm{QPCR}$ with specific primers and were normalised to the UBQ10 expression for two independent transgenic lines. mRNA levels are expressed as percentages in relation to a pFSD1::GUS seedling under low Cu conditions. Values are the means \pm SD of at least three biological replicates.

at around $0.2 \mu \mathrm{M} \mathrm{Cu}$ (Fig. 5a). The $50 \%$ maximum expression of cuprochaperone $C C H$ was around $0.3 \mu \mathrm{M} \mathrm{Cu}$ (Fig. 5a). CSD1 and CCS exhibited their 50\% maximum expression at around 0.25 and $0.3 \mu \mathrm{M} \mathrm{Cu}$, respectively (Fig. 5b). The expression patterns of these genes clearly delineated the transcriptional changes occurring within the $\mathrm{Cu}$ deficiency range and further suggest $\mathrm{Cu}$ concentrations of around $0.5 \mu \mathrm{M}$ to be the limit between sufficiency and deficiency, where plants sense low $\mathrm{Cu}$ supply and initiate molecular responses to alleviate it. 
(a)

(b)
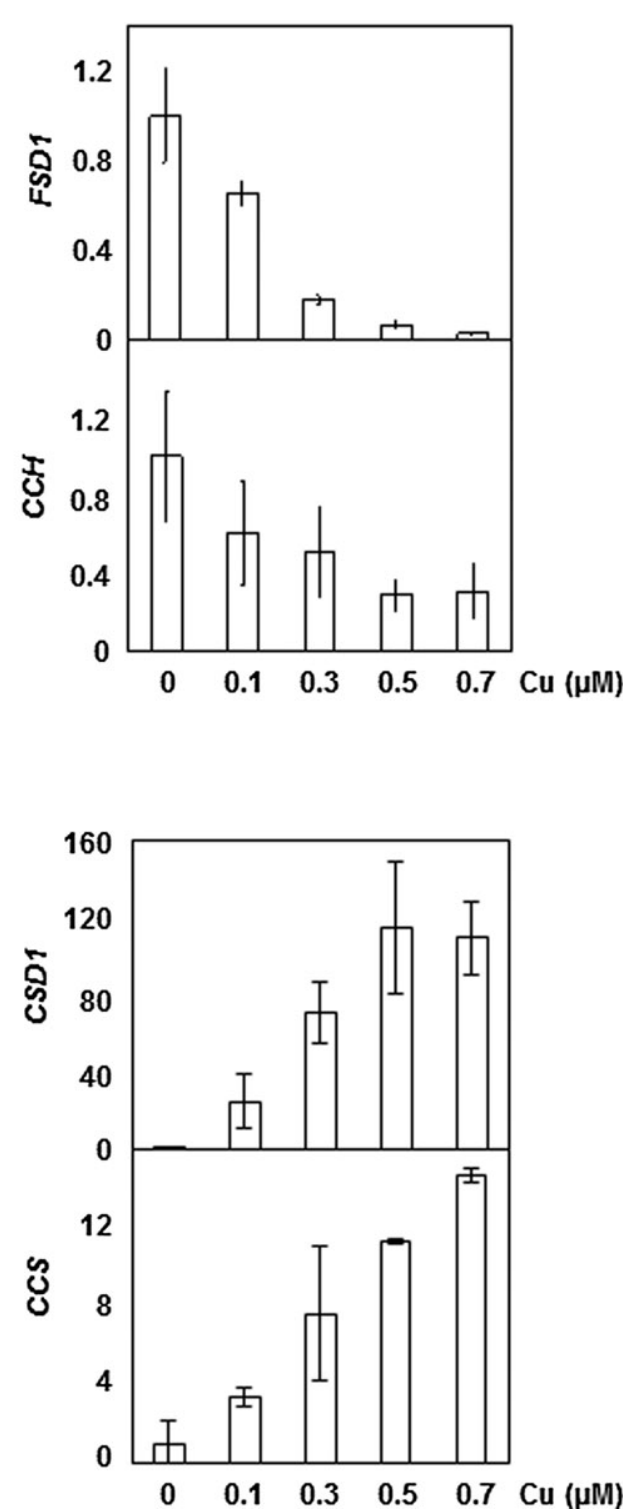

Fig. 5 Expression of the Cu status markers in the Arabidopsis seedlings grown on different $\mathrm{Cu}$-supplemented media. Relative expressions of the $\mathrm{Cu}$ deficiency markers FSD1 and CCH (a), and the Cu excess markers CSD1 and CCS (b). The total RNA from the 6-day-old WT seedlings grown on homemade MS media with different $\mathrm{Cu}$ concentrations was isolated and retrotranscribed to cDNA. The mRNA amounts of each gene were measured by GPCR with specific primers and were normalised to the UBQ10 expression. mRNA levels are expressed in relative units to the $0 \mu \mathrm{M}$ Cu-supplemented medium. Values are the means \pm SD of at least three biological replicates.

In light of this, the unknown and most Cu-regulated expressions of the overrepresented genes analysed under $\mathrm{Cu}$ deficiency (CAS) and $\mathrm{Cu}$ excess (SDH1-2) conditions (Fig. 2 and 3) were tested within a wide $\mathrm{Cu}$ concentration range (Fig. 6a and b). As shown in Fig. 6a, the CAS expression increased under low $\mathrm{Cu} v s$. high $\mathrm{Cu}$ conditions, with a similar pattern to the previous well-established $\mathrm{Cu}$ deficiency homeostasis markers (Fig. 5a). Furthermore, the CAS expression under different metal status indicated the $\mathrm{Cu}$ specificity of this response since other metals in excess had no inhibitory effects on induction with the
Cu-deficient MS medium (Fig. 6c). Conversely, excess Fe increased its expression, while it lowered under Fe deficiency conditions (Fig. S6, ESI $\dagger$ ). Interestingly, the CAS expression responded to both metals similarly to $F S D 1,{ }^{22,50}$ further reinforcing the proposed $\mathrm{Cu}-\mathrm{Fe}$ interaction. ${ }^{8,11,50} \mathrm{CAS}$ is required for photoacclimation in Chlamydomonas reinhardtii, and particularly for proper stomatal regulation in response to raised external $\mathrm{Ca}^{2+} .{ }^{51,52}$ These results suggest chloroplast to be a sensor of unbalanced $\mathrm{Cu}$ supply where signalling molecules, such as $\mathrm{Ca}^{2+}$, ROS and ABA, may participate in global plant responses to $\mathrm{Cu}$ status.

A possible cross-talk involving the antioxidant system, external $\mathrm{Ca}^{2+}$ and abscisic acid (ABA) hormone signalling has been proposed. ${ }^{53}$ Indeed, several genes related to ABA signalling were overrepresented under high $\mathrm{Cu}$ conditions (Table S1, $\mathrm{ESI}+$ ). Moreover $\mathrm{Ca}^{2+}$ fluxes and ROS production have already been reported to participate in both $\mathrm{Cu}$ signalling ${ }^{54}$ and circadian rhythm regulation. ${ }^{55}$ In light of this, some Cu-regulated categories in our microarray well fit processes that have been previously reported to be circadian clock-regulated: ion homeostasis, osmotic stress responses and cell growth. ${ }^{56,57}$

The SDH1-2 expression increased at Cu levels of $5 \mu \mathrm{M}$ in the growth medium (Fig. 6b), which represented $\mathrm{Cu}$ supra-optimal supply (>20 $\mu \mathrm{g} \mathrm{Cu}$ per gram of dry weight) (Fig. 1). ${ }^{31}$ Moreover, this induction was highly specific to $\mathrm{Cu}$ (Fig. 6d). A plausible explanation for the SDH1-2 function may be envisaged from the fact that $\mathrm{Cu}^{2+}$ has been reported to inhibit all the succinatelinked partial electron transfer reactions through its binding to active thiol groups before the site of entry of electrons from ascorbate. ${ }^{58}$ Thus, as previously suggested, SDH1-2 could contribute to the synthesis of complex II in order to restore mitochondrial electron transport. ${ }^{59}$ Mitochondria $\mathrm{Cu}$ homeostasis has been proven a key player in senescence and life span in other organisms, such as Caernorhabditis elegans. ${ }^{60}$ In agreement, our results indicate that mitochondria may be involved in the complex network of responses of higher plants to $\mathrm{Cu}$ status. Furthermore, these data indicate SDH1-2 as a new specific gene marker for mild $\mathrm{Cu}$ stress, which may prove useful for the detection of overdoses in Cu-containing agronomical treatments.

\section{Experimental}

\section{Plant growth conditions and treatments}

A. thaliana plants, ecotype Col 0 , and $s p l 7$ knockout plants ${ }^{10}$ were grown as previously described. ${ }^{33}$ The $\mathrm{MS}_{1 / 2}$ medium $(\mathrm{MS})^{30}$ was either commercial (Sigma; www.sigmaaldrich.com) or prepared in the laboratory as follows: macronutrients $12.5 \mathrm{ml}\left(\mathrm{NH}_{4} \mathrm{NO}_{3} 825 \mathrm{mg} \mathrm{l}^{-1}, \mathrm{KNO}_{3} 950 \mathrm{mg} \mathrm{l} \mathrm{l}^{-1}, \mathrm{MgSO}_{4} \cdot 7 \mathrm{H}_{2} \mathrm{O}\right.$ $90.35 \mathrm{mg} \mathrm{l}^{-1}, \mathrm{KH}_{2} \mathrm{PO}_{4} 85 \mathrm{mg} \mathrm{l}^{-1}$ and $\mathrm{CaCl}_{2} 166.25 \mathrm{mg} \mathrm{l}^{-1}$ ), micronutrients $0.5 \mathrm{ml}\left(\mathrm{H}_{3} \mathrm{BO}_{3} 3.1 \mathrm{mg} \mathrm{l} \mathrm{l}^{-1}, \mathrm{MnSO}_{4} \cdot \mathrm{H}_{2} \mathrm{O} 8.45 \mathrm{mg}\right.$ $\mathrm{l}^{-1}, \mathrm{ZnSO}_{4} \cdot 7 \mathrm{H}_{2} \mathrm{O} 4.3 \mathrm{mg} \mathrm{l} \mathrm{l}^{-1}, \mathrm{NaMoO}_{4} \cdot 2 \mathrm{H}_{2} \mathrm{O} 0.125 \mathrm{mg} \mathrm{l}^{-1}$ and $\left.\mathrm{CoCl}_{2} \cdot 6 \mathrm{H}_{2} \mathrm{O} 0.0125 \mathrm{mg} \mathrm{l}^{-1}\right)$, Fe-EDTA $2.5 \mathrm{ml}\left(\mathrm{FeSO}_{4} \cdot 7 \mathrm{H}_{2} \mathrm{O}\right.$ $13.9 \mathrm{mg} \mathrm{l}^{-1}$ and $\mathrm{Na}_{2}$ EDTA. $2 \mathrm{H}_{2} \mathrm{O} 18.63 \mathrm{mg} \mathrm{l}^{-1}$ ), KI $1.1 \mathrm{ml}$ (0.41 mg l $\mathrm{l}^{-1}$ ), MES $0.5 \mathrm{~g} \mathrm{l}^{-1}$, sucrose $10 \mathrm{~g} \mathrm{l}^{-1}$ and agar $8 \mathrm{~g} \mathrm{l}^{-1}$; pH 5.7 with $\mathrm{KOH}$. Variable $\mathrm{CuSO}_{4}$ concentrations were added 
(a)

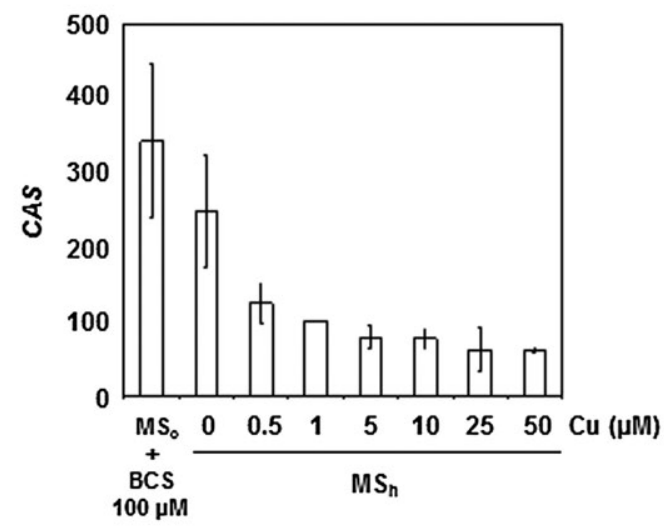

(c)

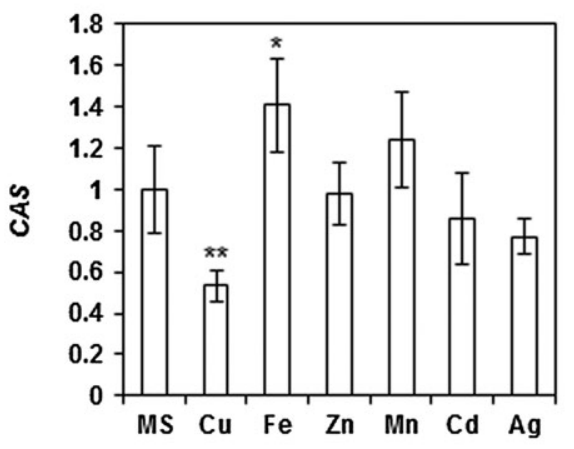

1

5

(d)

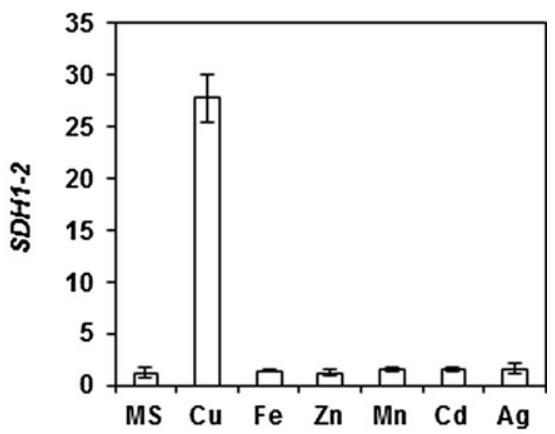

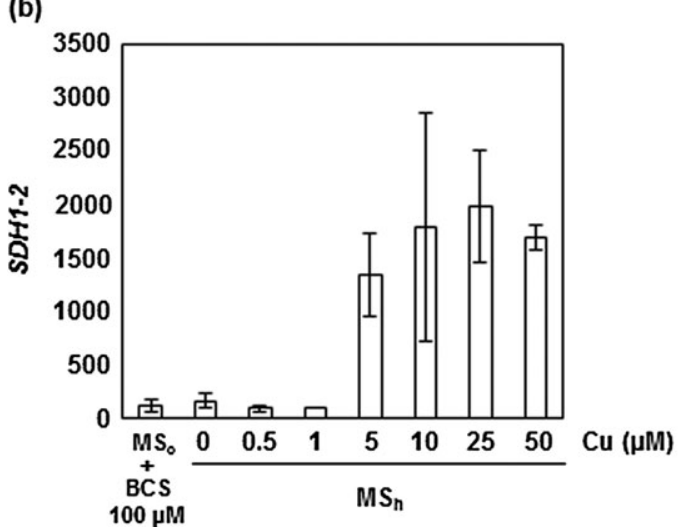

Fig. 6 Expression of the CAS and SDH1-2 genes in the Arabidopsis seedlings grown on different metal-supplemented media. Relative expressions of the CAS (a and c) and SDH1-2 ( $\mathrm{b}$ and $\mathrm{d}$ ) genes. The total RNA from the 6-day-old WT seedlings grown on MS media (commercial or homemade) supplemented with BCS or Cu, as indicated ( $a$ and $b$ ) or homemade MS media with $30 \mu \mathrm{M}$ of different metals ( $c$ and d), was isolated and retrotranscribed to cDNA. The mRNA amounts of each gene were measured by qPCR with specific primers and were normalised to the UBQ10 expression. mRNA levels are expressed as percentages in relation to the $1 \mu \mathrm{M}$ Cusupplemented medium ( $a$ and $b$ ) or as relative units to the MS ( $c$ and $d)$. Values are the means \pm SD of at least three biological replicates. Asterisks represent significant differences in relation to homemade MS medium ( $\left.{ }^{\star} P<0.05 ;{ }^{* *} P<0.01\right)$.

when indicated. Media were supplemented with BCS $100 \mu \mathrm{M}$ or ferrozine $300 \mu \mathrm{M}$ for the $\mathrm{Cu}$ - or Fe-deprived media, respectively. Plants were grown under a long day photoperiod $(16 \mathrm{~h}$ light-23 ${ }^{\circ} \mathrm{C} / 8 \mathrm{~h}$ dark-16 ${ }^{\circ} \mathrm{C} ; 16 \mathrm{~L} / 8 \mathrm{D}$ ), except for the gene expression analysis by real-time quantitative PCR on different $\mathrm{Cu}$-supplemented media where plants were grown under neutral photoperiod $\left(12 \mathrm{~h}\right.$ light- $23{ }^{\circ} \mathrm{C} / 12 \mathrm{~h}$ dark- $\left.16{ }^{\circ} \mathrm{C} ; 16 \mathrm{~L} / 8 \mathrm{D}\right)$. Samples were collected at around $4 \mathrm{~h}$ after the light has been switched on. Soil-grown plants were watered with MS solution and $\mathrm{CuSO}_{4}$ concentrations, as indicated. Lipid peroxidation was measured as MDA content. ${ }^{61}$ Chlorophyll content was determined by the trichlorometric method. ${ }^{62}$

\section{Gene expression by semi-quantitative and real-time} quantitative PCR

Total RNA was isolated from A. thaliana seedlings with Trizol Reagent (Ambion). RNA was quantified by UV spectrophotometry and its integrity was visually assessed on ethidium bromidestained agarose gels. Total RNA $(1.5 \mu \mathrm{g})$ was first converted into cDNA by reverse transcription using SuperScript II reverse transcriptase (Invitrogen) and anchored oligo(dT) ${ }_{15}$ (Roche).
Semi-quantitative PCRs (sqPCR) were performed with specific oligonucleotides (Table S4, ESI $\dagger$ ). Real-time quantitative PCRs (qPCR) were carried out with SYBR-Green qPCR Super-Mix-UDG with ROX (Invitrogen) and specific primers (Table S5, ESI $\dagger$ ) in a StepOnePlus Real-Time PCR System (Applied Biosystems) under 1 cycle of $95{ }^{\circ} \mathrm{C}$ for $2 \mathrm{~min}$ and 40 cycles consisting in $95^{\circ} \mathrm{C}$ for $30 \mathrm{~s}$ and $60^{\circ} \mathrm{C}$ for $30 \mathrm{~s}$. The results correspond to the comparative $\mathrm{Ct}$ (cycle threshold) method.

\section{Metal accumulation measurements}

Lyophilised samples were digested with $\mathrm{HNO}_{3}$ and $\mathrm{H}_{2} \mathrm{O}$ at $100{ }^{\circ} \mathrm{C}$. Digested samples were diluted with $\mathrm{H}_{2} \mathrm{O}$ milliQ (PURELAB Ultra; www.elgalabwater.com). $\mathrm{Cu}, \mathrm{Fe}$ and $\mathrm{Zn}$ contents were analysed by inductively coupled plasma mass spectroscopy ICP-MS (Perkin Elmer Optima 3200RL; www.PerkinElmer.com). These measurements were taken at the Unitat d'Anàlisi Elemental, Serveis Cientificotècnics at the Universitat de Barcelona.

\section{Obtaining transgenic chimeric plants}

An FSD1 promoter fragment (1193 bp) (pFSD1) and a modified promoter (1128 bp) with a 65-bp fragment deletion containing 
1 four GTAC boxes ( $\left.p F S D 1^{*}\right)$ were fused with the coding region of the $\beta$-glucuronidase (GUS) reporter as follows. The pFSD1 fragment was obtained from A. thaliana genomic DNA by PCR using the following specific primers, which introduce adequate restriction sites for cloning: FSD1 HindIII F/FSD1 BamHI R. Two fragments of $806 \mathrm{bp}$ and $361 \mathrm{bp}$ were obtained from $A$. thaliana genomic DNA by PCR by respectively using the following two pairs of specific primers: FSD1 HindIII F/FSD1-4GTAC R and FSD1-4GTAC F/FSD1 BamHI R, where FSD1-4GTAC F and R

10 were designed to be complementary. The $p F S D 1 *$ fragment was obtained by using the two previous primers in a PCR due to the complementary region of both fragments. The obtained promoter fragments were cloned at the multicloning site of the pFP101 vector ${ }^{63}$ with HindIII and BamHI restriction enzymes.

15 The C58 strain of Agrobacterium tumefaciens, transformed with this construct, was used to transform A. thaliana plants by following the floral dip protocol. ${ }^{49}$ Transgenic plants were selected by seed fluorescence.

Gene expression analysis by long oligonucleotide microarrays

Long oligonucleotide microarrays were provided by Dr David Galbraith (University of Arizona, www.ag.arizona.edu/microar ray/). The analysis was performed as described. ${ }^{64}$ Three biological replicates (6-day-old seedlings grown under a 16L/8D photoperiod) were obtained for each treatment (commercial $\mathrm{MS}_{1 / 2}$ with and without $\mathrm{Cu} 10 \mu \mathrm{M}$ ), and samples were taken consecutively at the same time during the photoperiod $(4 \mathrm{~h}$ after light has been switched on) to avoid differences in the diurnal or circadian regulations of the gene expression. For each biological replicate, two microarrays were hybridised for six microarrays. Only the spots for which valid data were obtained for at least four of the six hybridisations were selected. The data from two of the six microarrays were eliminated because of detected hybridisation problems. The median $\log _{2}$ ratio (by comparing high $\mathrm{Cu}$ status to low $\mathrm{Cu}$ status) was calculated. The gene list, ordered according to the mean $\log _{2}$ ratio, was analysed using the FatiScan (GEPAS, Gene Expression Pattern Analysis Suite, v3.1; http://babelomics.bioinfo.cipf.es/ fatiscan/cgi-bin/fatiscan.cgi) with 30 partitions and a two-tailed

40 Fisher's exact test with an adjusted $p$-value after correcting for multiple testing following the FDR procedure ${ }^{65}$ and the GeneCodis2.0 (http://genecodis.dacya.ucm.es/) programmes. Microarray raw data were deposited in the NCBI GEO database under accession number GSE13114.

\section{Computer-assisted sequence analysis}

The theoretical promoter sequence analysis was performed by the PLACE Web Signal Scan (www.dna.affrc.go.jp/htdocs/ PLACE/signalscan.html) and Patmatch from TAIR (www.arabi dopsis.org).

\section{Statistical analysis}

Statistical analysis of the relative expressions was performed by applying the comparison of the relative gene expressions $(P<$ 0.05), and was carried out using two-way ANOVA for the remaining parameters, while means were compared by the
Duncan test $(P \leq 0.05)$ with the InfoStat software, 2010 version (www.infostat.com.ar), or by the $t$-test with the GraphPad software (www.graphpad.com/quickcalcs/ttest1.cfm?Format=SD).

The expression levels for the microarrays were statistically analysed in a one-class response using a significance analysis of microarray $\left(\mathrm{SAM}^{66}\right)$, a criterion for the selection of fold change $\log _{2} \geq|1|$ and a false discovery rate (FDR) of $<2 \%$.

\section{Conclusions}

The current study shows a microarray analysis of $A$. thaliana plants grown under mild $\mathrm{Cu}$ deficiency and excess conditions which underscore gene expression changes under nutrient sufficiency limits. A CuAt database was created to compile relevant data on $\mathrm{Cu}$ homeostasis in plants and responses to different $\mathrm{Cu}$ status. This study uncovers a new mild $\mathrm{Cu}$ deficiency responsive gene, chloroplast $\mathrm{Ca}^{2+}$ transducer CAS. Reiterative GTAC boxes in proximal promoter regions may act as a cis element responsible for gene expression induction under Cu-deficiency conditions, as shown herein for FSD1 regulation. In the case of mild $\mathrm{Cu}$ excess, the flavoprotein subunit of succinate dehydrogenase in mitochondria SDH1-2 is proposed as a new molecular marker that might facilitate prompt detection of $\mathrm{Cu}$ overdoses in crops treated with $\mathrm{Cu}$-based fungicides or pesticides.

\section{Acknowledgements}

We thank Dr Toshiharu Shikanai for the spl7 mutant and the Unitat d'Anàlisi Elemental, Serveis Cientificotècnics at the Universitat de Barcelona. This work has been supported by Grants BIO2011-24848 and CSD2007-00057 to L.P. from the Spanish Ministry of Economy and Competitiveness, and by FEDER funds from the European Union and the Generalitat Valenciana (Regional Valencian Government; ACOMP07-159). N.A.-C., A.G.-M. and A.P.-G were recipients of predoctoral fellowships from the Spanish Ministry of Economy and Competitiveness.

\section{Notes and References}

1 M. S. G. V. Z. Van Zwieten, Lukas, Rural Industries Research and Development Corporation, 2007.

$2 \mathrm{H}$. Fones and G. M. Preston, The impact of transition metals on bacterial plant disease, FEMS Microbiol. Rev, 2012, DOI: 10.1111/1574-6976.12004.

3 A. N. Petit, F. Fontaine, P. Vatsa, C. Clement and N. VaillantGaveau, Fungicide impacts on photosynthesis in crop plants, Photosynth. Res., 2012, 111, 315-326.

4 J. Montag, L. Schreiber and J. Schonherr, An in vitro study on the postinfection activities of copper hydroxide and copper sulfate against conidia of Venturia inaequalis, J. Agric. Food Chem., 2006, 54, 893-899.

5 D. Rusjan, M. Strlič, D. Pucko and Z. Korošec-Koruza, Copper accumulation regarding the soil characteristics in 
Sub-Mediterranean vineyards of Slovenia, Geoderma, 2007, 141, 111-118.

6 T. Kuflik, D. Prodorutti, A. Frizzi, Y. Gafni, S. Simon and I. Pertot, Optimization of copper treatments in organic viticulture by using a web-based decision support system, Comput. Electron. Agric., 2009, 68, 36-43.

Q4 7 S. Houlton, R. Soc. Chem., 2009.

8 S. Puig, N. Andres-Colas, A. Garcia-Molina and L. Penarrubia, Copper and iron homeostasis in Arabidopsis: responses to metal deficiencies, interactions and biotechnological applications, Plant, Cell Environ., 2007, 30, 271-290.

9 M. Pilon, C. M. Cohu, K. Ravet, S. E. Abdel-Ghany and F. Gaymard, Essential transition metal homeostasis in plants, Curr. Opin. Plant Biol., 2009, 12, 347-357.

10 H. Yamasaki, M. Hayashi, M. Fukazawa, Y. Kobayashi and T. Shikanai, SQUAMOSA Promoter Binding Protein-Like7 Is a Central Regulator for Copper Homeostasis in Arabidopsis, Plant Cell, 2009, 21, 347-361.

11 M. Bernal, D. Casero, V. Singh, G. T. Wilson, A. Grande, H. Yang, S. C. Dodani, M. Pellegrini, P. Huijser, E. L. Connolly, S. S. Merchant and U. Kramer, Transcriptome Sequencing Identifies SPL7-Regulated Copper Acquisition Genes FRO4/FRO5 and the Copper Dependence of Iron Homeostasis in Arabidopsis, Plant Cell, 2012, DOI: tpc.111.090431 [pii]10.1105/tpc.111.090431.

12 B. E. Kim, T. Nevitt and D. J. Thiele, Mechanisms for copper acquisition, distribution and regulation, Nat. Chem. Biol., 2008, 4, 176-185.

3013 V. Sancenon, S. Puig, H. Mira, D. J. Thiele and L. Penarrubia, Identification of a copper transporter family in Arabidopsis thaliana, Plant Mol. Biol., 2003, 51, 577-587.

14 L. Penarrubia, N. Andres-Colas, J. Moreno and S. Puig, Regulation of copper transport in Arabidopsis thaliana: a biochemical oscillator?, JBIC, J. Biol. Inorg. Chem., 2010, 15, 29-36.

15 V. Sancenon, S. Puig, I. Mateu-Andres, E. Dorcey, D. J. Thiele and L. Penarrubia, The Arabidopsis copper transporter COPT1 functions in root elongation and pollen development, J. Biol. Chem., 2004, 279, 15348-15355.

16 A. Garcia-Molina, N. Andres-Colas, A. Perea-Garcia, S. Del Valle-Tascon, L. Penarrubia and S. Puig, The intracellular Arabidopsis COPT5 transport protein is required for photosynthetic electron transport under severe copper deficiency, Plant J., 2011, 65, 848-860.

17 S. Klaumann, S. D. Nickolaus, S. H. Furst, S. Starck, S. Schneider, H. Ekkehard Neuhaus and O. Trentmann, The tonoplast copper transporter COPT5 acts as an exporter and is required for interorgan allocation of copper in Arabidopsis thaliana, New Phytol., 2011, 192, 393-404.

18 N. J. Robinson and D. R. Winge, Copper metallochaperones, Annu. Rev. Biochem., 2010, 79, 537-562.

19 C. Andreini, L. Banci, I. Bertini and A. Rosato, Occurrence of copper proteins through the three domains of life: a bioinformatic approach, J. Proteome Res., 2008, 7, 209-216.
20 J. L. Burkhead, K. A. Reynolds, S. E. Abdel-Ghany, C. M. Cohu and M. Pilon, Copper homeostasis, New Phytol., 2009, 182, 799-816.

21 F. Sommer, J. Kropat, D. Malasarn, N. E. Grossoehme, X. Chen, D. P. Giedroc and S. S. Merchant, The CRR1 nutritional copper sensor in Chlamydomonas contains two distinct metal-responsive domains, Plant Cell, 2010, 22, 4098-4113.

22 S. E. Abdel-Ghany, P. Muller-Moule, K. K. Niyogi, M. Pilon and T. Shikanai, Two P-type ATPases are required for copper delivery in Arabidopsis thaliana chloroplasts, Plant Cell, 2005, 17, 1233-1251.

23 H. Yamasaki, S. E. Abdel-Ghany, C. M. Cohu, Y. Kobayashi, T. Shikanai and M. Pilon, Regulation of copper homeostasis by micro-RNA in Arabidopsis, J. Biol. Chem., 2007, 282, 16369-16378.

24 S. E. Abdel-Ghany and M. Pilon, MicroRNA-mediated systemic down-regulation of copper protein expression in response to low copper availability in Arabidopsis, J. Biol. Chem., 2008, 283, 15932-15945.

25 T. del Pozo, V. Cambiazo and M. Gonzalez, Gene expression profiling analysis of copper homeostasis in Arabidopsis thaliana, Biochem. Biophys. Res. Commun., 2010, 393, 248-252.

26 L. J. Shin, J. C. Lo and K. C. Yeh, Copper chaperone antioxidant protein1 is essential for copper homeostasis, Plant Physiol., 2012, 159, 1099-1110.

27 C. C. Chen, Y. Y. Chen and K. C. Yeh, Effect of Cu content on the activity of $\mathrm{Cu} / \mathrm{ZnSOD} 1$ in the Arabidopsis SUMO E3 ligase siz1 mutant, Plant Signaling Behav., 2011, 6, 1428-1430.

28 J. Xu, Y. S. Tian, R. H. Peng, A. S. Xiong, B. Zhu, X. F. Jin, J. J. Gao, X. L. Hou and Q. H. Yao, Yeast copper-dependent transcription factor ACE1 enhanced copper stress tolerance in Arabidopsis, BMB Rep., 2009, 42, 752-757.

29 H. I. Jung, S. R. Gayomba, M. A. Rutzke, E. Craft, L. V. Kochian and O. K. Vatamaniuk, COPT6 is a plasma membrane transporter that functions in copper homeostasis in Arabidopsis and is a novel target of SQUAMOSA promoter-binding protein-like 7, J. Biol. Chem., 2012, 287, 33252-33267.

30 T. Murashige and F. Skoog, A revised medium for rapid growth and bioassays with tobacco tissue cultures, Physiol. Plant., 1962, 15, 473-497.

31 H. Märschner, , Academic Press, London, 2002.

32 H. Wintz, T. Fox, Y. Y. Wu, V. Feng, W. Chen, H. S. Chang, T. Zhu and C. Vulpe, Expression profiles of Arabidopsis thaliana in mineral deficiencies reveal novel transporters involved in metal homeostasis, J. Biol. Chem., 2003, 278, 47644-47653.

33 N. Andres-Colas, V. Sancenon, S. Rodriguez-Navarro, S. Mayo, D. J. Thiele, J. R. Ecker, S. Puig and L. Penarrubia, The Arabidopsis heavy metal P-type ATPase HMA5 interacts with metallochaperones and functions in copper detoxification of roots, Plant J., 2006, 45, 225-236.

34 E. Himelblau, H. Mira, S. J. Lin, V. C. Culotta, L. Penarrubia and R. M. Amasino, Identification of a functional homolog 
of the yeast copper homeostasis gene ATX1 from Arabidopsis, Plant Physiol., 1998, 117, 1227-1234.

35 S. E. Abdel-Ghany, J. L. Burkhead, K. A. Gogolin, N. AndresColas, J. R. Bodecker, S. Puig, L. Penarrubia and M. Pilon, AtCCS is a functional homolog of the yeast copper chaperone Ccs1/Lys7, FEBS Lett., 2005, 579, 2307-2312.

36 C. C. Chu, W. C. Lee, W. Y. Guo, S. M. Pan, L. J. Chen, H. M. Li and T. L. Jinn, A copper chaperone for superoxide dismutase that confers three types of copper/zinc superoxide dismutase activity in Arabidopsis, Plant Physiol., 2005, 139, 425-436.

37 M. Ashburner, C. A. Ball, J. A. Blake, D. Botstein, H. Butler, J. M. Cherry, A. P. Davis, K. Dolinski, S. S. Dwight, J. T. Eppig, M. A. Harris, D. P. Hill, L. Issel-Tarver, A. Kasarskis, S. Lewis, J. C. Matese, J. E. Richardson, M. Ringwald, G. M. Rubin and G. Sherlock, Gene ontology: tool for the unification of biology. The Gene Ontology Consortium, Nat. Genet., 2000, 25, 25-29.

38 L. Decaria, I. Bertini and R. J. Williams, Copper proteomes, phylogenetics and evolution, Metallomics, 2011, 3, 56-60.

39 G. León, L. Holuigue and X. Jordana, Mitochondrial complex II Is essential for gametophyte development in Arabidopsis, Plant Physiol., 2007, 143, 1534-1546.

40 N. Suzuki, G. Miller, J. Morales, V. Shulaev, M. A. Torres and R. Mittler, Respiratory burst oxidases: the engines of ROS signaling, Curr. Opin. Plant Biol., 2011, 14, 691-699.

41 M. C. Caillaud, L. Paganelli, P. Lecomte, L. Deslandes, M. Quentin, Y. Pecrix, M. Le Bris, N. Marfaing, P. Abad and B. Favery, Spindle assembly checkpoint protein dynamics reveal conserved and unsuspected roles in plant cell division, PLoS One, 2009, 4, e6757.

42 N. Andres-Colas, A. Perea-Garcia, S. Puig and L. Penarrubia, Deregulated copper transport affects Arabidopsis development especially in the absence of environmental cycles, Plant Physiol., 2010, 153, 170-184.

43 T. Fujimori, E. Sato, T. Yamashino and T. Mizuno, PRR5 (PSEUDO-RESPONSE REGULATOR 5) plays antagonistic roles to CCA1 (CIRCADIAN CLOCK-ASSOCIATED 1) in Arabidopsis thaliana, Biosci., Biotechnol., Biochem., 2005, 69, 426-430.

44 J. C. Schoning, C. Streitner, I. M. Meyer, Y. Gao and D. Staiger, Reciprocal regulation of glycine-rich RNAbinding proteins via an interlocked feedback loop coupling alternative splicing to nonsense-mediated decay in Arabidopsis, Nucleic Acids Res., 2008, 36, 6977-6987.

45 M. R. Willmann and R. S. Poethig, Conservation and evolution of miRNA regulatory programs in plant development, Curr. Opin. Plant Biol., 2007, 10, 503-511.

46 I. E. Sonderby, F. Geu-Flores and B. A. Halkier, Biosynthesis of glucosinolates-gene discovery and beyond, Trends Plant Sci., 2010, 15, 283-290.

47 E. Ramirez-Parra, M. A. Lopez-Matas, C. Frundt and C. Gutierrez, Role of an atypical E2F transcription factor in the control of Arabidopsis cell growth and differentiation, Plant Cell, 2004, 16, 2350-2363.
48 S. Han, R. Tang, L. K. Anderson, T. E. Woerner and Z. M. Pei, A cell surface receptor mediates extracellular $\mathrm{Ca}(2+)$ sensing in guard cells, Nature, 2003, 425, 196-200.

49 S. J. Clough and A. F. Bent, Floral dip: a simplified method for Agrobacterium-mediated transformation of Arabidopsis thaliana, Plant J., 1998, 16, 735-743.

50 B. M. Waters, S. A. McInturf and R. J. Stein, Rosette iron deficiency transcript and microRNA profiling reveals links between copper and iron homeostasis in Arabidopsis thaliana, J. Exp. Bot., 2012, 63, 5903-5918.

51 H. Nomura, T. Komori, M. Kobori, Y. Nakahira and T. Shiina, Evidence for chloroplast control of external $\mathrm{Ca} 2+$-induced cytosolic $\mathrm{Ca} 2+$ transients and stomatal closure, Plant J., 2008, 53, 988-998.

52 S. Weinl, K. Held, K. Schlucking, L. Steinhorst, S. Kuhlgert, M. Hippler and J. Kudla, A plastid protein crucial for Ca2+-regulated stomatal responses, New Phytol., 2008, 179, 675-686.

53 W. H. Wang, X. Q. Yi, A. D. Han, T. W. Liu, J. Chen, F. H. Wu, X. J. Dong, J. X. He, Z. M. Pei and H. L. Zheng, Calcium-sensing receptor regulates stomatal closure through hydrogen peroxide and nitric oxide in response to extracellular calcium in Arabidopsis, J. Exp. Bot., 2012, 63, 177-190.

54 C. Jonak, H. Nakagami and H. Hirt, Heavy metal stress. Activation of distinct mitogen-activated protein kinase pathways by copper and cadmium, Plant Physiol., 2004, 136, 3276-3283.

55 A. N. Dodd, M. J. Gardner, C. T. Hotta, K. E. Hubbard, N. Dalchau, J. Love, J. M. Assie, F. C. Robertson, M. K. Jakobsen, J. Goncalves, D. Sanders and A. A. Webb, The Arabidopsis circadian clock incorporates a cADPR-based feedback loop, Science, 2007, 318, 1789-1792.

56 S. L. Harmer, J. B. Hogenesch, M. Straume, H. S. Chang, B. Han, T. Zhu, X. Wang, J. A. Kreps and S. A. Kay, Orchestrated transcription of key pathways in Arabidopsis by the circadian clock, Science, 2000, 290, 2110-2113.

57 R. Schaffer, J. Landgraf, M. Accerbi, V. Simon, M. Larson and E. Wisman, Microarray analysis of diurnal and circadian-regulated genes in Arabidopsis, Plant Cell, 2001, 13, 113-123.

58 A. I. Cederbaum and W. W. Wainio, Binding of iron and copper to bovine heart mitochondria. 3. Role of mitochondrial phospholipids and thiols, J. Biol. Chem., 1972, 247, 4615-4620.

59 V. N. Popov, A. T. Eprintsev, D. N. Fedorin and A. U. Igamberdiev, Succinate dehydrogenase in Arabidopsis thaliana is regulated by light via phytochrome A, FEBS Lett., 2010, 584, 199-202.

60 C. Q. Scheckhuber, J. Grief, E. Boilan, K. Luce, F. DebacqChainiaux, C. Rittmeyer, R. Gredilla, B. O. Kolbesen, O. Toussaint and H. D. Osiewacz, Age-related cellular copper dynamics in the fungal ageing model Podospora anserina and in ageing human fibroblasts, PLoS One, 2009, 4, e4919.

$61 \mathrm{~J}$. A. Buege and S. D. Aust, Microsomal lipid peroxidation, Methods Enzymol., 1978, 52, 302-310.

1 
62 T. Parsons and J. Strickland, Discussion of spectrophotometric determination of marine-plant pigments, with revised equations for ascertaining chlorophyll-a and carotenoids, J. Mar. Res., 1963, 21, 105-156.

563 S. Bensmihen, J. Giraudat and F. Parcy, Characterization of three homologous basic leucine zipper transcription factors (bZIP) of the ABI5 family during Arabidopsis thaliana embryo maturation, J. Exp. Bot., 2005, 56, 597-603.

64 E. Bueso, S. Alejandro, P. Carbonell, M. A. Perez-Amador, J. Fayos, J. M. Belles, P. L. Rodriguez and R. Serrano, The lithium tolerance of the Arabidopsis cat2 mutant reveals a cross-talk between oxidative stress and ethylene, Plant J., 2007, 52, 1052-1065.

65 Y. Benjamini, Y. Hochberg and J. Roy, Controlling the false discovery rate: a practical and powerful approach to multiple testing, J. R. Stat. Soc. Ser. B, 1995, 57, 289-300.

66 V. G. Tusher, R. Tibshirani and G. Chu, Significance analysis of microarrays applied to the ionizing radiation response, Proc. Natl. Acad. Sci. U. S. A., 2001, 98, 5116-5121. 